p-ISSN. 2086-9029

e-ISSN. 2654-5675

Vol. 22 No. 1, Hlm. 1-158, Juni 2020

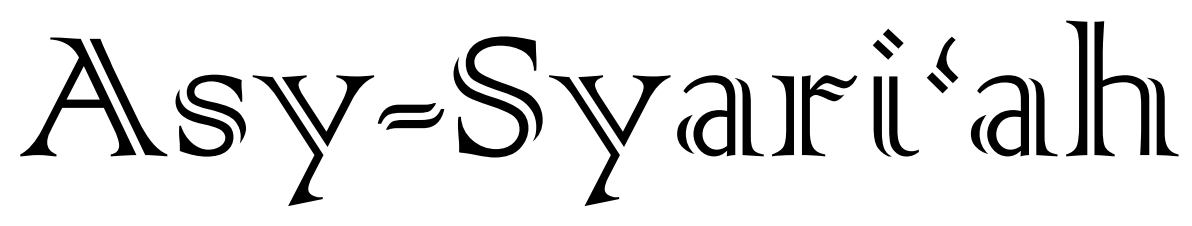

- Hukum Waris Islam Sebagai Instrumen Kepemilikan Harta

$(1-20)$ Hafidz Taqiyyudin

- Komparasi Metodologi Hukum Aliran Maqasidi dan Aliran Syakli

$(21-34)$ Hudzaifah Achmad Qotadah

- Reinterpretasi Hak Ijbar dalam Hukum Perkawinan Islam di Keluarga $(35-50)$ Pesantren

Kudrat Abdillah

- Dimensi Kondisionalitas dan Fleksibilitas Al-Quran bagi Implementasi $(51-66)$ Fatwa DSN-MUI tentang Produk Bank Syariah

Ahmad Hasan Ridwan, Asep Rahmat

- Validitas Hadis Tidak Ada Kisas bagi Orang Tua yang Membunuh Anaknya

Moh. Ahsanuddin Jauhari, Enceng Arif Faizal, Syahrul Anwar, Atep Mastur, Deden Najmudin

- Penguatan Resolusi Konflik Berbasis Tradisi Sunnah Nabi

Alamsyah

- Sistem Perencanaan, Pelaksanaan dan Pengawasan Industri Halal di Wilayah Provinsi Banten

Akhyakudin, Suja'i, Muhammad Abduh

- Reformulation of Family Legal in Indonesia for Female Maslahah

Wahidullah, Murniati, Yushinta Eka Farida, Jumaiyah

- The Concept and Aplication of Covenant in Financing Gold Pawn By Sharia Bank in West Java

Neni Nuraeni, Dewi Sulastri, Zulbaidah

- Tinjauan Sosiologi Hukum tentang Kepatuhan Masyarakat terhadap ( $147-158)$ Undang-Undang Wakaf

Deden Effendi

FACULTY OF SHARIA AND LAW

STATE ISLAMIC UNIVERSITY SUNAN GUNUNG DJATI BANDUNG-INDONESIA IN COLLABORATION WITH ASOSIASI SARJANA SYARIAH INDONESIA 


\section{Asy-Syari'ah}

Volume 22, Number 1, 2020

\section{EDITOR-IN-CHIEF}

Ine Fauzia

\section{EDITORIAL BOARD}

Sofyan al-Hakim, UIN Sunan Gunung Djati Bandung, Indonesia Deni Kamaludin Yusup, UIN Sunan Gunung Djati Bandung, Indonesia Meria Utama, Fakultas Hukum Univrsitas Sriwijaya, Indonesia Dewi Mayaningsih, UIN Sunan Gunung Djati Bandung, Indonesia Andrey Sujatmiko, Fakultas Hukum Universitas Trisakti, Jakarta, Indonesia Hetty Hassanah, Universitas Komputer Indonesia, Indonesia

\section{PEER-REVIEWERS}

Muhammad Irfan Helmy, IAIN Salatiga, Semarang, Indonesia Ahmad Ali Nurdin, UIN Sunan Gunung Djati Bandung Tajul Arifin, UIN Sunan Gunun Djati Bandung, Indonesia Mohamad Anton Athoillah, UIN Sunan Gunung Djati Bandung, Indonesia Mrs. Renny Supriyatni, Universitas Padjadjaran, Indonesia Ahmad Tholabi Karlie, UIN Syarif Hidayatullah Jakarta, Indonesia Ija Suntana, UIN Sunan Gunung Djati Bandung, Indonesia Zezen Zaenal Mutaqin, University of California, Los Angeles, United States Ahmad Fathonih, UIN Sunan Gunung Djati Bandung, Indonesia Rahman Syamsuddin, Universitas Islam Negeri Alauddin Makassar, Indonesia

\section{PROOFREADER/DESIGN COVER}

Nanang Sungkawa

\section{LAYOUT EDITOR}

Opik Rozikin

Asy-Syari' ah has been accredited based on the determination of Director General of Research and Development Strengthening, Ministry of Research, Technology and Higher Education of Republic of Indonesia, No. 14/E/KPT/2019 (valid until 2023). 


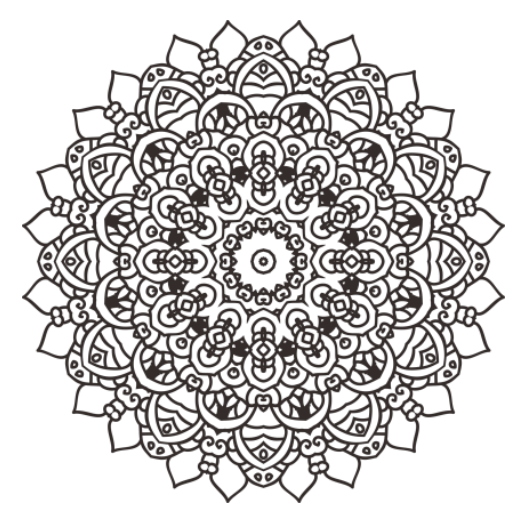

\title{
KOMPARASI METODOLOGI HUKUM ALIRAN MAQASIDI DAN ALIRAN SYAKLI
}

\section{Hudzaifah Achmad Qotadah \\ Jabatan Fiqh dan Usul, Akademi Pengajian Islam, Universiti Malaya, Malaysia E-mail: hudzaifahachmad47@gmail.com}

\begin{abstract}
Islamic thought has been developing whenever so there are various streams within the legal methodology especially within the figh approach which emerged from the Sahabat era such as fiqh 'Abdullah Ibn Mas'ud, fiqh Umar, fiqh Ibn Umar, etc and therefore the differences between the Companions has given rise to different tendencies of thought between each other both those belonging to the ahl athar or ahl ra'i groups. The obvious difference is that the tendency of thinking based on maqasidi is colored by ijtihad Umar while the tendency of thinking supported syakli (formalism) is more clearly seen within the fiqh of Abdullah Ibn Umar and these streams are created within supported the legal references employed by every group in order to do Istinbath al-hukm. So, a Fuqaha who always looks at the objectives of Islamic Sharia in conducting legal terminology is spoken as Maqasidi while jurists who always look to the form or format in legal rest are spoken as Syakli. Therefore, during this study, the author is inspired to check and analyze the thoughts of the jurists towards legal methodology supported the flow of maqasidi and also syakli.
\end{abstract}

Keywords: fuqah, maqasid, syakli 


\begin{abstract}
Abstrak: Pemikiran Islam terus berkembang pada setiap masanya, sehingga telah muncul berbagai macam aliran dalam bidang metodologi hukum, utamanya dalam pendekatan fiqh. Perbedaan tersebut muncul sejak masa sahabat ra, seperti 'Abdullah Ibn Mas'ud, fiqh Umar, fiqh Ibn Umar dan sebagainya. Perbedaan di kalangan para sahabat ini telah melahirkan kecenderungan pemikiran yang berbeda di antara mereka, baik yang tergolong dalam kelompok ahl athar maupun ahl ra'i. Perbedan yang jelas terjadi adalah kecenderungan pemikiran berasaskan terhadap maqasidi yang diwarnai ijtihad Umar, sedangkan kecenderungan pemikiran berasaskan syakli (formalisme) lebih jelas terlihat pada fiqh Abdullah Ibn Umar. Aliran-aliran ini dibentuk berdasarkan kepada mashâdir hukum yang digunakan oleh setiap kelompok dalam melakukan istinbath hukum. Seorang fuqaha yang senantiasa melihat secara objektif syariat Islam dalam melakukan istinbath hukum disebut sebagai Maqâsidi. Sedangkan fuqaha yang senantiasa melihat kepada rupa bentuk atau format dalam ber-istinbath hukum disebut sebagai Syakli. Oleh karena itu, dalam artikel ini penulis terdorong untuk mengkaji dan menganalisis pemikiran para fuqaha terhadap metodologi hukum berasaskan aliran maqasidi dan juga syakli.
\end{abstract}

Kata-kata Kunci: fuqaha, maqasid, syakli 


\section{Pendahuluan}

Allah SWT telah memberikan nikmat yang teristimewa kepada setiap makhlukNya yaitu berupa akal. Keistimewan akal ini membolehkan manusia berfikir dalam mengurus kehidupan dengan sempurna dan bermanfaat, yang berbeda dengan makhluk-Nya yang lain yang tidak dianugerahhi akal. ${ }^{1}$ Keistimewan tersebut juga yang membolehkan manusia untuk mencari kebenaran agar mereka dapat meraih hakikat keyakinan terhadap sesuatu kebenaran, sehingga mereka mampu memahami syariat-Nya dengan pemahaman yang benar dan lurus. ${ }^{2}$

Setiap aliran pemikriran maupun pandangan tidak tercetus begitu saja dan tiba-tiba, melainkan berkesinambungan dari tragedi tertentu atau latarbelakang tertentu, sehingga tidak dapat dinafikan bahwa setiap insan memiliki perbedaan pemikiran dalam memahami sesuatu, tidak terkecuali dalam memahami syariat Islam. Sebab, setiap individu memiliki pola fikir yang tersendiri berdasarkan kepada latar belakang keilmuan masing-masing yang mana pada asalnya mereka berbeda pandangan karena ingin memenuhi kepentingan hidup dan menjauhkan hidup mereka dari kerusakan. ${ }^{3}$

Pemikiran disebut sebagai percobaan yang berasaskan kepada keupayaan akal yang telah dilakukan oleh para fuqaha Islam, dengan tujuan untuk menjelaskan suatu nas yang bersumber kepada al-Quran dan Assunnah. Percobaan yang dimaksud ialah percobaan untuk memahami dan melakukan istinbath hukum-hukum agama yang berkaitan dengan kehidupan manusia. Maka semua hukum yang dihasilan oleh pemikiran fuqaha dalam sesuatu nas melalui proses ijtihad, yang bersandarkan kepada keupayaan akal mereka dalam menghasilkan sebuah pemahaman dalam ber-istinbat hukum. ${ }^{4}$

Adapun pemahaman ialah sesuatu yang sifatnya dinamis, banyak dipengaruhi oleh corak pemikiran seseorang. Corak ini bukan saja terbentuk berdasarkan kemampuan akal dalam berfikir, tetapi juga dapat dipengaruhi oleh lingkungan dan tempat tinggal mereka masing-masing. Karena itulah perbedaan pemikiran atau pemahaman yang terjadi terhadap fuqaha dapat disebabkan oleh lingkungan tempat mereka tinggal ataupun keadaan saat itu ketika ijtihad dilakukan. Karenanya, pemikiran Islam telah berkembang setiap masanya sehingga telah melahirkan berbagai aliran dalam metodologi hukum terutama dalam pendekatan fiqh. ${ }^{5}$

\footnotetext{
${ }^{1}$ Muhammad Ropingi, Posisi Akal dalam Perspektif Dalil Akidah, Jurnal: Risalah, Vol. 4, No.2 (Januari 2018), hlm. 85 .

${ }^{2}$ Muhamamad Rashidi Wahab, Mohd Faizul Azmi, Kedudukan Akal dalam Pendalilan Akidah, Jurnal: Teknologi, Vol.63, No.1 (Juli 2013), hlm. 31-32.

${ }^{3}$ Maad Ahmad, Muhammad Yosef Niteh, Mohd Rofaizal Ibrahim, Antara Akal dan Wahyu Dari Perspektif Islam, E-Prosiding Persidangan Antarabangsa Sains Sosial dan Kemanusiaan, Jilid 2, Kolej Universiti Islam Antarabangsa Selangor, KUIS, Malaysia, 2017, hlm 1. http://conference.kuis.edu.my/pasak2017 /index.php/ prosiding/prosiding-jilid2.

${ }^{4}$ Muhammad al-Bahi, al Fikr al Islamifi Tatawwurih, (Kaherah: Dar al Fikr, 1971), hlm. 7.

${ }^{5}$ Mahmood Zuhdi Ab Majid (2000), "Fiqh Malaysia: Konsep dan Cabaran", dalam Paizah Ismail dan Ridzwan Ahmad, Fiqh Malaysia, Kuala Lumpur: Akademi Pengajian Islam, Universiti Malaya, hlm. 6.
} 
Perbedaan pemikiran yang terjadi di antara para sahabat atau fuqaha, membentuk kecenderungan yang berbeda dalam fiqh sepertimana perbedaan yang paling terlihat jelas ialah antara kecenderungan maqasidi (objectivist), yang lebih terlihat pada fiqh Umar Ibn al Khattab dan kecenderungan syakli (formalist) yang terlihat jelas pada figh putra beliau Abdullah Ibnu Umar dan ini yang kemudian mempengaruhi golongangolongan yang berbeda dalam melakukan istinbath hukum. Karena itu, kelompok yang menggunakan pendekatan syakli dikenal sebagai tradisionalis, sedangkan pendekatan maqasidi disebut sebagai reformis. ${ }^{6}$ Perbedaan pandangan atau pemikiran dalam menginterpretasi wahyu telah ada di masa Nabi Muhammad SAW. Dan ia mengizinkan para sahabatnya untuk berijtihad dalam memahami nas, sabda beliau:

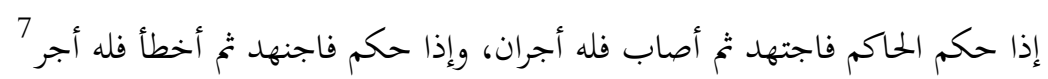

Apabila seseorang hakim itu berhukum dan berijtihad kemudian dia betul dalam ijtihadnya, maka dia memperolehi dua pahala, dan apabila seseorang hakim itu berhukum dan berijtihad kemudian dia salah dalam ijtihadnya, maka dia memperolehi satu pahala.

Dari hadis di atas dapat kita pahami bahwa Rasullah SAW memberikan izin kepada para sahabatnya untuk menggunakan akal pikiran dalam berijtihad, jika tidak mendapati hukumnya baik dalam al-Quran ataupun hadist. Inilah yang membuat para sahabat terkadang berbeda pemikiran dalam memahai suatu nas, walaupun mereka belajar dari satu guru yaitu Rasulullah SAW.

Dalam satu hadis lain beliau bersabda:

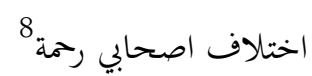

Bahwa perbedaan pendapat di kalangan para sahabat saya merupakan satu rahmat.

\section{Metode Penelitian}

Penulis menggunakan metode kualitatif yang mana penelitian kualitatif sering menjadi dasar asumsi penelitian dalam bidang ilmu syariat, ilmu sosial, dan ilmu humaniora. Penelitian kualitatif dimaksudkan untuk membangun pengetahuan melalui penemuan dan pemahaman situasi, sama ada secara tekstual maupun kontekstual. Adapun penelitian

\footnotetext{
${ }^{6}$ Mohd Ramli, Muhammad Sayuti Mansor, Pendekatan Wasatiyyah Bagi Menangani Ikhtilaf Fiqh Dalam Kalangan Masyarakat Islam Nusantara, Seminar Internasiolan "Islam di Alam Melayu kali ke-V ", 12-14 September 2015 di College of Islamic Studies Prince of Songkla University, Pattani, Thailand, hlm. 132. Lihat disini: http://eprints.um.edu.my/14748/1/0001.pdf.

${ }^{7}$ Muslim, Shahih Muslim, (Beirut: Dar al Fikr, cet.1, 1424H/2003), kitab: al-Aqdiyah, bab: Bayan Ajru al Hakim Idza ljtahada Faashaba aw Akhtha, no. hadis 1716, juz 1, hlm. 865.

${ }^{8}$ Abu Bakr Ahmad ibn al-Hussain al-Bayhaqi, al-Madkhal ila as-Sunani al-Kubra, (Kuwait: Dar al-Khulafa lil Kutub al-Islami, t.c, 1404H), jilid 1 , hlm 145-146. https://arablib.com/?view=book\&lid=2\&rand1 = QHNUSklqXm54MWto\&rand2=a3d5JFVDMWUoc1Zw
} 
kualitatif berusaha menyelidiki sebuah fenomena dan gejala sosial yang timbul dari sebab suatu perkara yang termasuk dalam nilai dan norma masyarakat, bahkan permasalahan yang timbul di tengah-tengah kehidupan manusia. Metode kualitatif yang menjadi dasar penulis berusaha membuat sebuah gambaran konstruktif, kompleks, laporan terperinci, menganalisis kata perkata dari perspektif beberapa responden maupun eksplorasi studi pada situasi yang berjalan secara alami. ${ }^{9}$

Penelitian ilmiah yang diaktegorikan sebagai penelitian pustaka menunjukkan makna penting dari seluruh rangkaian metodologi penelitian. Penelitian kepustakaan memberikan beberapa tujuan antara lain yaitu menghubungkan penelitian dengan pelbagai literatur yang sesuai dengan tema penelitian, menginformasikan kepada khalayak terhadap hasil penelitian yang dilakukan saat itu dengan kesamaan tema penelitian-penelitian lain, dan menyempurnakan celah kekurangan penelitian-penelitian sebelumnya. ${ }^{10}$ Adapun kajian pustaka dimaksudkan untuk, menganalisis, meringkas, serta menafsirkan teori maupun konsep-konsep yang bertalian dengan penelitian yang sedang berlangsung. ${ }^{11}$

Adapun pengumpulan data yang dilakukan dalam penelitian ini adalah menggunakan metode pustaka baik mengenai buku-buku, jurnal-jurnal ataupun referesi yang terkait dengan pembahasan kajian ini yaitu mengenai analisis pemikiran fuqaha terhadap metodologi hukum berasaskan aliran maqasidi dan aliran syakli. Dan diharapkan pembahasan daripada penelitian ini dapat menjadi sebuah disiplin ilmu yang lebih konstruktif dari kajian atau penelitian yang telah dijalankan sebelumnya.

\section{Hasil Penelitian dan Pembahasan}

Imam Izzudin Ibn Abdul Salam dalam kitabnya menyatakan bahwa mayoritas kemaslahatan dunia dan keburukannya diketahui dengan akal begitu juga kebanyakan syariat $^{12}$. Maka ilmu maqasid shariah memiliki kepentingan yang teramat penting dalam mengukur dan memeprtimbangkan sesuatu persmasalahan agar terjamin mendatangkan kemaslahatan dan mencegah keburukan. Oleh sebab itu, secara teori aliran maqasidi ialah aliran yang merujuk dan sentiasa mengambil pendekatan yang lebih mementingkan objektif sebagaimana yang terdapat dalam pendekatan maqâsid al-shariah. ${ }^{13}$ Sebagaimana yang telah banyak dibahaskan oleh fuqaha bahawa maqasid al-shariah, terbagi kepada tiga bagian: ${ }^{14}$

\footnotetext{
${ }^{9}$ Iskandar, Metodologi Penelitian Kualitatif, (Jakarta: Gaung Persada, 2009) cet.1 hlm. 11.

${ }^{10}$ Creswell John W., 2010, Research Design: Qualitative, Quantitative, and Mixed Methods Approaches, 3th, terjemahan Achmad Fawaid, Yogyakarta, hlm. 40.

${ }^{11}$ Gary Anderson, Nancy Arsenault, 1998, Fundamentals of Educational Research, 2nd Edition, The Falmer Press, Philadelphia, hlm. 83

${ }_{12}$ 'Izz al-Din Ibn 'Abd al-Salam, Qawaid al-Ahkam Fi Masalih al-Anam, muhaqqiq: Usman Jumah Dhamiriyah \& Nazih Kamal Hammad(Damashiq: Dar al-Qalam, cet. 1,1421H/200), Juz 1, hlm. 7.

${ }^{13}$ Muhammad Mansif al-Asri, Al-Fikr al-Maqasidi Inda al-Imam Malik, (Kaherah: Dar al-Hadith, 2008), p. 28

${ }^{14}$ Abu Ishaq al-Shatibi, Al-Muwafaqat fi Ushul al-Shariah, (Kaherah: Dar Ibn Affan, cet1, 1417H/1997), Juz 2, hlm. 17.
} 
Pertama, Dharuriyyat (kepentingan hidup), yaitu segala apa yang paling penting dalam kehidupan manusia entah bagi tujuan kebaikan agama dan hidup di dunia. Dan jika kepentingan asas ini tidak dipenuhi maka kehidupan manusia akan menjadi rusak dan merugi baik di dunia atau di akhirat. Kepentingan dharuriyat terbagi menjadi lima atau disebut sebagai dharuriyyat al-khams, yaitu: ${ }^{15}$

Menjaga agama (حفظ الدين) "Dan Aku tidak menciptakan jin dan manusia, melainkan supaya mereka menyembah-Ku. (OS: 51: 56).

Menjaga jiwa (حفظ النفس) "Dan dalam qishash itu ada (jaminan kelangsungan) hidup bagimu, hai orang-orang yang berakal, supaya kamu bertakwa" (OS: 2: 179).

Menjaga akal (حفظ العقل) "Hai orang-orang yang beriman, sesungguhnya (meminum) khamar, berjudi, (berkorban untuk) berhala, mengundi nasib dengan panah, adalah perbuatan keji termasuk perbuatan syaitan. Maka jauhilah perbuatan-perbuatan itu agar kamu mendapat keberuntungan. (QS: 5: 90).

Menjaga kehormatan atau keturunan (حفظ النسل) "Dan janganlah kamu mendekati zina; sesungguhnya zina itu adalah suatu perbuatan yang keji. Dan suatu jalan yang buruk". (QS: 17: 32).

Menjaga harta (حفظ المال) "Dan janganlah kamu menghambur-hamburkan (hartamu) secara boros. Sesungguhnya pemboros-pemboros itu adalah saudara-saudara setan, dan setan itu adalah sangat ingkar kepada Rabbnya". (OS: 17: 26-27).

Kedua, Hajiyyat (keperluan hidup) ialah kepentingan yang dibutuhkan oleh umat manusia untuk memberi kemudahan kepada hamba-Nya dan menghapuskan kesempitan yang membawa kepada kesulitan dan kesukaran kepada mereka. Dan jika kepentingan asas ini tidak dipenuhi tidaklah membawa kepincangan dalam hidup manusia sebagaimana yang berlaku dalam kepentingan asas dharuriyyat, tetapi ia boleh memunculkan kesulitan hidup manusia. ${ }^{16}$

Ketiga, Tahsiniyyat (pelengkap hidup) ialah kepentingan yang tidak sampai kepada kepentingan dharuriyat atau kepentingan hajiyyat. Namun kepentingan ini perlu dipenuhi untuk memberi kesempurnaan dan keindahan bagi hidup manusia. ${ }^{17}$

Dan antara ulama yang terkenal yang membawa kepada pendekatan berasaskan maqasid ini ialah al-Hakim al-Tirmizi, al-Imam al-Haramain, Nizamuddin Abu Ali al-Shashi alHanafi, imam al-Ghazali, imam Shihab al-Din al-Qarafi, Ibn Taimiyyah, Ibn Qayyim alJawziyyah, imam al-Shatibi, Muhammad al-Thahir Ibn Ashur dan sebagainya. ${ }^{18}$

\footnotetext{
${ }^{15}$ Ibid., hlm. 17-18.

${ }^{16}$ Ibid., hlm. 21.

${ }^{17}$ Muhammad Said al-Yubi, Maqasid al-Shariah al-islamiyyah Wa 'Alaqatuha Bi al-Adillah al-Shar'iyyah, (Riyadh: Dar al-Hijrah, cet.1, 1418H/1998), hlm. 329.

${ }^{18}$ Ziyad Muhammad Ahmidan, Maqasid al-Shariah al-Islamiyyah, (Beirut: Muassasah al-Risalah Nashirun, cet.1, 1429H/2008), hlm. 37-50.
} 
Sedangkan aliran syakli ialah aliran yang merujuk kepada pendekatan yang lebih mementingkan terhadap format dalam proses istinbath hukum atau disebut sebagai aliran dengan pendekatan secara literal atau dzahir nas saja. Oleh sebab itu, aliran ini tidak menjadikan maqasid itu sebagai pendekatan yang utama sehingga aliran ini berbeda dengan pendekatan aliran maqasidi. Berdasarkan kepada metode yang digunakan oleh aliran syakli ini lebih bersifat tekstual maka aliran ini mempunyai ikatan dengan pendekatan yang digunakan oleh madhab al-Zahiri. Aliran ini telah diperkenalkan oleh para fuqaha bermadhab Zahiri yang telah diasaskan oleh imam Ibn Hazm. ${ }^{19}$

\section{Konsep Asas}

Sebenarnya, para ulama ushuliyyin telah banyak membincangkan persoalan ta'lil al-ahkam, khususnya dalam kerangka perbahasan qiyas, penerimaan mashalah, istihsan, 'urf dan sebagainya. Begitu juga dalam maqasid al-shariah bahwa persoalan ta'lil alahkam tidak boleh lari dari perbincangan, sebab konsep ta'lil al-ahkam ini teramat penting. Hal demikian ini sebagaimana yang telah dinyatakan oleh Ridzwan Ahmad bahwa penerimaan konsep maslahah baik yang ada dalam usul al-figh ataupun maqasid al-shariah merupakan hasil dari kewujudan konsep ta'lil al -ahkam dan persoalan mengenai ta'lil al-ahkam bukanlah persoalan yang mudah untuk diperkatakan secara detail dan terarah. Hal ini disebabkan terdapat berbagai dakwaan yang berbeda dalam kalangan ulama usul al-fiqh mengenai konsep tersebut. ${ }^{20}$

Karenanya, ada dakwaan yang menyatakan bahwa sebagian ulama menolak konsep ta'lil al-ahkam dan sebahagian lainnya menyatakan bahawa konsep tersebut telah disepekati oleh para ulama sehingga menjadikan konsep ini sebagai tonggak kepada penerimaan maqasid al-shariah. ${ }^{21}$ Perbedaan dakwaan dalam konsep ta'lil al-ahkam disebabkan oleh perbedaan mereka dalam arti 'illah itu sendiri. ${ }^{22}$ Sebagaimana yang telah dinukil oleh $\mathrm{Dr}$ Umar bin Shalih di dalam kitabnya bahwa sebagian ulama, termasuk Imam al-Shatibi, menyatakan pada hakikatnya 'illah itu adalah maqasid sehingga tidak ada perbedaan antara 'illah dan juga maqasid. Maka syarat-syarat 'illah ialah syarat-syarat maqasid. ${ }^{23}$

Ringkasnya, penerimaan dan penolakan terhadap konsep ta'lil al-ahkam memberi kesan terhadap proses pembinaan sesuatu hukum untuk menghasilkan kesimpulan hukum ataupun fatwa, khususnya terhadap persoalan-persoalan yang berlaku pada saat ini. Maka

\footnotetext{
${ }^{19}$ Muhammad Ben Umar, Ibn Hazm Wa Arauhu al-Ushuliyyah, (Beirut: Dar al-Kutub al-Ilmiyah, cet.1, 2007), hlm. 22-23.

${ }^{20}$ Ridzwan Ahmad, Permasalahan Ta'lil Al-Ahkam Sebagai Asas Penerimaan Maqasid Al-Shariah Menurut Ulama Usul, Jurnal figh, vol 5, (Kuala Lumpur: Akademi Pengajian Islam Universiti Malaya, 2008), hlm. 170.

${ }^{21}$ Ibid., hlm. 170.

${ }^{22}$ Adil al-Shuwaikh, Ta'lil Al-Ahkam Fi Al-Shariah Al-Islamiyyah, (Tanta: Dar al-Bashariyah Lil Saqafah Wa al-Ulum, cet.1, 1420H/2000), hlm.23.

${ }_{23}^{23}$ Umar Shalih Umar, Maqasid al-Shariah inda al-Imam al-izz Ibn Abd al-Salam, (Urdun: Dar al- Nafais, cet.1, 1423H/2003), hlm. 93-94.
} 
jumhur fuqaha yang menerima konsep ini menunjukkan bahwa sumber hukum bukanlah hanya al-Quran dan as-Sunnah saja. Akan tetapi, sumber hukum seperti qiyas, istihsan, masalih al-mursalah dan sebagainya juga merupakan sumber hukum yang dapat digunakan untuk berijitihad terhadap persoalan-persoalan baru yang berlaku ${ }^{24}$, sehingga para ulama akan melakukan ijtihad terhadap persoalan terkini berlandaskan kepada nas-nas yang ada baik melalui lafaz-lafaznya ataupun 'illah-illahnya. ${ }^{25} \mathrm{Hal}$ ini diyakini bahwa segala insiden yang berlaku di dunia ini tidaklah pernah sunyi daripada hukum-hukum Allah ${ }^{26}$ yang bersandarkan pada bahwa setiap hukum itu memilik 'illah yang tersendiri. ${ }^{27}$

Manakala para fuqaha yang menolak konsep ta'lil al-ahkam atau fuqaha yang berasaskan terhadap aliran syakli, menunjukkan bahwa mereka tidak menerima sumber hukum lainnya dalam ber-istinbat seperti qiyas, istihsan, masalih al-mursalah dan lain sebagainya. Maka daripada semua pembahasan di atas kita dapati natijah bahwa penerimaan ataupun penolakan terhadap konsep ta'lil al-ahkam amat memberi kesan terhadap pembinaan metodologi hukum yang mereka gunakan baik terhadap hukum berasaskan kepada aliran maqasidi ataupun aliran syakli. ${ }^{28}$

\section{Pemikiran Fuqaha Aliran Maqasidi dan Syakli terhadap Metodologi Hukum}

Secara umum metodologi hukum yang digunakan oleh masing-masing fuqaha baik aliran maqasidi ataupun aliran syakli sangat berbeda. Perbedaan tersebut terjadi terhadap penggunanan masadir al-ahkam yaitu dalil-dalil shariah yang digunakan dalam proses men-istinbatkan hukum-hukum Islam atau hukum-hukum syariah. ${ }^{29}$ Antara metodologi hukum yang digunakan oleh fuqaha yang berasaskan terhadap aliran maqasidi ialah al-Quran, al-Sunnah, Ijma', Qiyas, Istihsan, Sad al-Dharai', Maslahah alMursalih dan lain sebagainya. Adapun metodologi hukum yang digunakan oleh fuqaha aliran syakli ialah hanya terbatas pada tiga sumber hukum ialah al-Quran, al-Sunnah dan Ijma'yang hanya terbatas kepada ljma' para sahabat saja.

${ }^{24}$ Lihat, Ridzwan Ahmad, Permasalahan Ta'lil Al-Ahkam Sebagai Asas Penerimaan Maqasid Al-Shariah Menurut Ulama Usul, hlm. 171-173.

${ }^{25}$ Abd al-Rahim bin al-Hasan al-Isnawi, Nihayat al-Sul fi Sharh Minhaj al-Wusul ila 'Ilm al-Usul, (Kaherah: 'Alam al-Kutub, t.c, t.t), jilid 4, hlm. 57. https://ia802707.us.archive.org/1/items/nssmonssmo/nssmo4.pdf.

${ }^{26}$ Muhammad al-Amidi, Ghayat al-Maram fi 'Ilm al-Kalam, Tahqiq: Hasan Mahmud 'Abd al-Latif, (Kaherah: al-Majelis al-'Ala lil Suun al-Islamiyah, t.t), hlm. 239-241.

${ }^{27}$ Jamal al-Din Abi Amr Uthman bin 'Amr ibn al-Hajib, Muntaha al-Wusul wa al-Amal fi 'Ilmay al-Usul wa alJadal, (Beirut: Dar al-Kutub al-llmiyyah, cet.1, 1985), hlm. 180-181. https://iag0270g.us.archive.org/27/items/ mwaiojbh/mwaiojbh.pdf

${ }^{28}$ Lihat, Abu Ishaq al-Shatibi, Al-Muwafaqat fi Ushul al-Shariah, hlm. 21-23.

${ }^{29}$ Wahbah al-Zuhayli, Usul al-Fiqh al-Islami, (Damshiq: Dar al-Fikr, cet.1, 1406H/1986), Juz 1, hlm. 417. 
Jadwal metodologi hukum aliran maqasidi dan syakli seperti berikut:

\begin{tabular}{cc}
\hline Aliran Maqasidi & Aliran Syakli \\
\hline Al-Quran & Al-Quran \\
Al-Hadist & Al-Sunnah \\
ljma' & ljma (sahabat saja) \\
Qiyas & \\
Istihsan & \\
Maslahah al-Mursalah & \\
Sad al-Dharai' & \\
Al-Urf & \\
\hline
\end{tabular}

Sumber: Diolah oleh penulis 2020

Bagi pemikiran yang berasaskan aliran maqasidi mereka melihat sumber hukum seperti qiyas merupakan usaha yang penuh kesungguhan untuk mendapakan kebenaran. Adapun sadd al-dharai' mereka melihat bahwa metode ini ialah menggunakan jalan maslahah sebagai cara untuk menolak atau menghadang mafsadah. ${ }^{30}$ Manakala pemikiran yang berasaskan terhadap aliran syakli khususnya bagi Ibn Hazm sebagai pengasas madhab yang hanya melihat kepada tekstual nash (ظواهر النصوص) saja, mereka melihat bahawa ijma' selain dariapada ijma para sahabat tidak boleh dijadikan hujjah dalam pembinaan sesuatu hukum. Hal ini sepertimana yang telah beliau sebut di dalam kitabnya (لا اجماع الا اجماع الصحابة رضي الله عنهم), maksudnya tidak ada ijma' kecuali ijma' sahabat. ${ }^{31}$

Sementara metode qiyas beliau menyatakan bahwa tidak boleh berhukum dalam permasalahan agama dengan menggunakan qiyas atau akal karena menurut beliau bahwa al-Quran dan al-Sunnah telah menjelaskan semua hukum-hukumnya sehingga tidak boleh ber-hujjah dengan metode qiyas selama terdapat nas. ${ }^{32}$ Beliau ber-hujjah dengan firman-Nya: "dan Kami turunkan kepadamu Al-Quran menjelaskan tiap-tiap sesuatu dan menjadi hidayah petunjuk, serta membawa rahmat dan berita yang menggembirakan, bagi orang-orang Islam". (QS: 16: 89) "pada hari ini, Aku telah sempurnakan bagi kamu agama kamu, dan Aku telah cukupkan nikmat-Ku kepada kamu, dan aku telah redhakan Islam itu menjadi agama untuk kamu". (OS: 5: 3)

Dengan demikian dapat kita simpulkan bahwa metodologi hukum yang digunakan oleh aliran syakli hanya terbatas kepada tiga masdar hukum saja ialah al-Quran, alHadist, dan ijma' sahabat serta menolak semua sumber-sumber hukum yang didasarkan pada penggunaan akal seperti istihsan, qiyas, maslahah al-mursalah, al-'urf dan lain sebagainya.

$3^{\circ}$ Lihat, Ridzwan Ahmad, Permasalahan Ta'lil Al-Ahkam Sebagai Asas Penerimaan Maqasid Al-Shariah Menurut Ulama Usul, hlm. 182-184.

${ }^{31}$ Ibn Hazm, al-Ihkam Fi Usul al-Ahkam, (Beirut: Dar al-Afaq al-Jadidah, t.t), Juz 4, hlm. 147.

${ }^{32}$ Ibn Hazm, al-Muhalla Bial-Atsar, (Beirut: Dar al-Kutub al-Ilmiyyah, cet.3, 2003), juz 1, hlm. 78. 


\section{Contoh Masalah Hukum antara Aliran Maqasidi dan Aliran Syakli}

Zakat padi atau pertanian

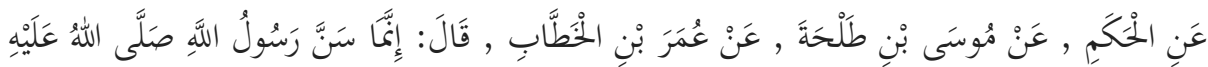

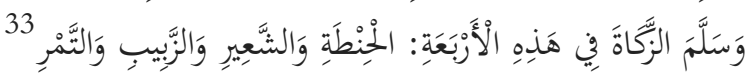

Dari Hakim dari Musa Ibn Talhah dari Umar Ibn Khatab berkata: sesunguhnya Rasullah

S.A.W bersabda bahawa zakat dikenakan atas 4 hal yaitu gandum (al-hinthah), barli (asy-sya'ir), anggur kering (az-zabib), dan kurma (at-tamr).

Jika melihat terhadap metodologi hukum yang digunakan oleh fuqaha aliran syakli maka mereka akan menetapkan bahawa zakat tanaman hanya dikenakan bagi 4 jenis hasil saja sepertimana yang terdapat dalam hadis di atas. ${ }^{34}$ Manakala fuqaha aliran maqasidi mereka akan melihat kepada objektif dan berkata bahwa 4 jenis makanan yang telah disebut oleh Rasulullah SAW itu mempunyai arti bahwa yang dikenakan zakat ialah apa saja makanan ruji masyarakat setempat. Sebab empat jenis makanan itulah yang bersifat ruji pada zaman itu. Dengan demikian zakat selain dari empat jenis itupun tetap dikenakan zakat seperti padi karena beras merupakan makanan ruji dalam masyarakat tertentu seperti Malaysia dan Indonesia. ${ }^{35}$

Membaca al-Quran bagi orang junub dan haid

Firman-Nya:

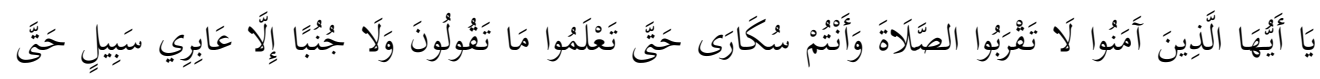
تَغْتَسِلُوا

Wahai orang-orang yang beriman, janganlah kamu hampiri sembahyang (mengerjakannya) sedang kamu dalam keadaan mabuk, hingga kamu sedar dan mengetahui akan apa yang kamu katakan. Dan janganlah pula (hampiri masjid) sedang kamu dalam keadaan Junub (berhadas besar) - kecuali kamu hendak melintas saja - hingga kamu mandi bersuci." (Q.S: An-Nisaa: 43)

Bagi fuqaha yang berpendekatan terhadap aliran syakli seperti Ibn Hazm, beliau menyatakan bahwa yang dilarang dari ayat di atas hanya terhad kepada orang junub yang ingin melakukan salat dan menghampiri masjid. Oleh sebab itu, menurut beliau orang junub dan orang haid boleh membaca al-Quran dan menyentuhnya. Selain itu,

\footnotetext{
${ }^{33}$ Abu al-Hasan 'Ali ibn 'Umar ibn Ahmad ibn Mahdi ibn Mas'ud ibn al-Nu'man ibn Dinar ibn 'Abdullah alBaghdadi al-Daraqutni, Sunan Al-Daraqutni, (Beirut: Muassasah al-Risalah, cet.1, 2004), Kitab: al-Zakat, Bab: Laisa Fi Khadarawat Shadaqah, No. hadis 1913, Juz 2, hlm. 480.

${ }^{34}$ Lihat, Ibn Hazm, al-Muhalla Bi al-Atsar, juz 4, hlm. 26.

35 Mahmood Zuhdi Haji Abd Majid, Maqasid Syariah Sebagai Pendekatan Bagi Realisasi Ajaran Islam di Malaysia: Satu Prospek, hal 5. Diaskes pada hari Ahad 9 Feb 2020, 18:14. https://www.academia.edu /30256412 /maqasid_syariah_sebagai_pendekatan_bagi_realisasi_ajaran_islam_di_malaysia_satu_prospek.
} 
menurut beliau jika ada yang membedakan antara orang junub dengan orang haid dalam persoalan membaca al-Quran dengan melihat terhadap masa lamanya, sehingga orang haid kerana masanya lebih lama kemudian diperbolehkan. Maka menurut beliau tidak ada gunanya berdalih atau berhujjah masa waktu ini bila membava itu sendiri dibolehkan. ${ }^{36}$

Manakala aliran maqasidi akan melihat kepada sumber hukum lainnya selain daripada ayat al-Quran saja dan menurut kebanyakan fuqaha yang berasaskan terhadap aliran maqasidi menyatakan bahwa orang junub ataupun hadi tidak diperbolehkan untuk membaca al-Quran ataupun menyentuhnya sepertimana sabda Nabi s.a.w:

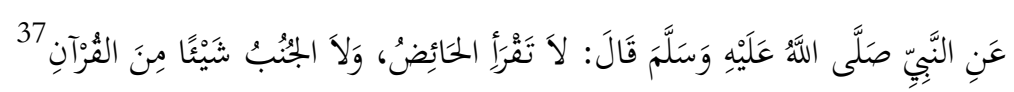

Dari Nabi Muhammad SAW bersabda: janganlah wanita haid dan orang junub membaca sesuatu pun dari al-Quran.

Mawarith

Kasus hak waris ibu dan bapak yang mewarisi bersama dengan suami atau isteri si mayit atau dalam fiqh mawarith kasus ini dikenal sebagai kasus Gharrawayn atau Umariyatayn. Firman-Nya:

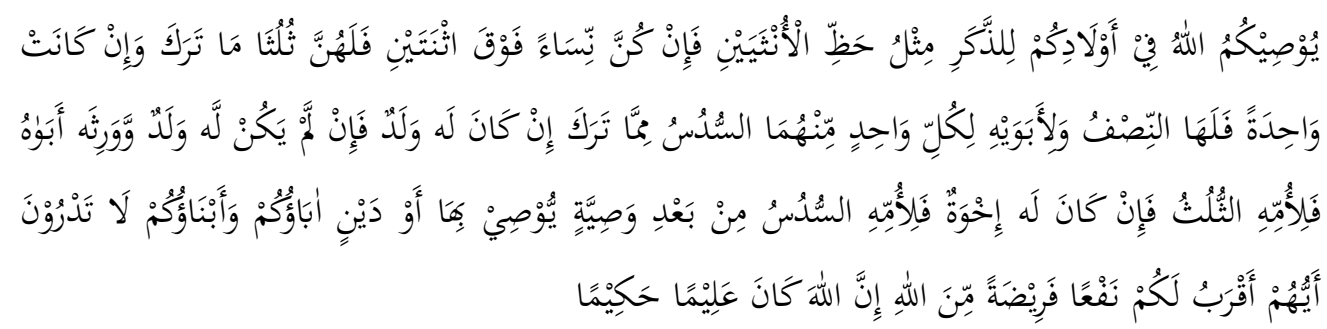

"Allah perintahkan kamu mengenai (pembahagian harta pusaka untuk) anak-anak kamu, yaitu bahagian seorang anak lelaki menyamai bahagian dua orang anak perempuan. Tetapi jika anak-anak perempuan itu lebih dari dua, maka bahagian mereka ialah dua pertiga dari harta yang ditinggalkan oleh si mati. Dan jika anak perempuan itu seorang saja, maka bahagiannya ialah satu perdua (separuh) harta itu. Dan bagi ibu bapa (si mati), tiap-tiap seorang dari keduanya: satu perenam dari harta yang ditinggalkan oleh si mati, jika si mati itu mempunyai anak. Tetapi jika si mati tidak mempunyai anak, sedang yang mewarisinya hanyalah kedua ibu bapanya, maka bahagian ibunya ialah satu pertiga. Kalau pula si mati itu mempunyai beberapa orang saudara (adik-beradik), maka bahagian ibunya ialah satu perenam. (Pembahagian itu) ialah sesudah diselesaikan wasiat yang telah diwasiatkan oleh si mati, dan sesudah dibayarkan hutangnya. Ibu-bapa kamu dan anak-anak kamu, kamu tidak mengetahui siapa di antaranya yang lebih dekat

\footnotetext{
${ }^{36}$ lihat, Ibn Hazm, al-Muhalla Bi al-Atsar, Juz 1, hlm. 95-96.

${ }^{37}$ At-Tirmidzi, Sunan at -Tirmidzi, (Beirut: Dar al-Gharib al-Islamiy, cet.1, 1996), Kitab: Al-Thaharah, Bab: Ma Jaa fi al-Junub Wa al-Haid Annaha La Yaqraani al-Quran, no. hadis 131, juz 1, hlm. 174
} 
serta banyak manfaatnya kepada kamu (Pembahagian harta pusaka dan penentuan bahagian masing-masing seperti yang diterangkan itu ialah) ketetapan dari Allah; sesungguhnya Allah adalah Maha Mengetahui, lagi Maha Bijaksana." (Q.S: An-Nisaa: 11)

Ayat ini menerangkan bahawa ibu mendapat $1 / 3$ bahagian harta jika si mayit tidak memiliki anak yang menjadi ahli warisnya. Namun, menurut Umar Ibn Khattab dan beliau termasuk sahabat yang lebih kepada pendekatan maqasidi, beliau menetapkan bagian ibu itu hanya $1 / 3$ dari sisa (thuluth al-baqi). Sebab menurutnya jika ibu mendapat 1/3 dari seluruh harta maka bahagian ibu menjadi lebih besar dari bahagian ayah. Maka pembagian seperti ini menyalahi kaedah umum yang seharusnya bagian laki-laki itu harus dua kali lipat daripada bagian perempuan. ${ }^{38}$ Manakala bagi fuqaha yang berasaskan terhadap aliran syakli seperti Imam Ibn Hazm akan tetap menetapkan bahawa bahagian ibu ialah $1 / 3$ dari seluruh harta dan tidak boleh mentakwil ayat sehingga merubah format pada ayat itu sendiri.

\section{Simpulan}

Kesimpulan hukum yang terjadi pada zaman sahabat, tabi'iin ataupun para ulama lainnya merupakan hasil produk pemahaman mereka terhadap permasalahan hukum yang terjadi pada saat itu di tengah komunitas masyarakat berdasarkan al-Quran dan Assunnah. Namun, perkembangan dunia pada hari ini jelas sangat berbeba dengan perkembangan dunia sebelumnya. Karenanya, banyak ulama menyatakan akan keperluan kepada fiqh semasa atau kontemporer dengan menggali sumber hukum Islam yang ada seperti al-Quran dan al-Hadist, ljma' qiyas dan lain sebagainya dalam rangka menghasilkan kesimpulan ijtihad yang berasaskan pada maslahah umat manusia di dunia dan akhirat sehingga prinsip utama syariah tidak boleh dipandang ringan atau tidak diberikan perhatian khususnya dalam persoalan-persoalan semasa yang terjadi pada saat ini.

Berdasarkan kajian yang telah di huraikan di atas, penulis berpandangan bahwa kedua-dua pendekatan ini baik pendekatan maqasidi ataupun syakli mempunyai kelebihan masing-masing. Akan tetapi, menurut hemat penulis bahwa pendekatan aliran maqasidi dilihat lebih praktikal dan lebih efektif dalam menangani persoalan-persoalan hukum yang lebih bersifat semasa atau kontemporer dimana pendekatan aliran maqasidi akan dapat membantu para mujtahid dalam melakukan proses ijtihad untuk mengeluarkan hukum yang bersesuaian dengan syara' yang mampu mendatangkan kebaikan dan menolak kerusakan ataupun keburukan yang dapat menimpa manusia atau biasa dikenal dengan جلب المصالح ودرء المفاسد.

\footnotetext{
${ }^{38}$ Syuhada, Bagaian Waris Ibu Dalam Gharrawayn: Analisis ljtihad Umar Dan Ibn Abbas Dalam Bagian Waris lbu, Jurnal Tafaqquh, Vol.2, No.1, (Juni 2014), hlm 79-84.
} 


\section{DAFTAR PUSTAKA}

'Izz al-Din Ibn 'Abd al-Salam, Qawaid al-Ahkam Fi Masalih al-Anam, muhaqqiq: Usman Jumah Dhamiriyah \& Nazih Kamal Hammad, Damashiq: Dar al-Oalam, cet. $1,1421 \mathrm{H} / 2001$.

Abd al-Rahim bin al-Hasan al-Isnawi, Nihayat al-Sul fi Sharh Minhaj al-Wusul ila 'Ilm alUsul, Kaherah: 'Alam al-Kutub, t.c, t.t.

Abu al-Hasan 'Ali ibn 'Umar ibn Ahmad ibn Mahdi ibn Mas'ud ibn al-Nu'man ibn Dinar ibn 'Abdullah al-Baghdadi al-Daraqutni, Sunan Al-Daraqutni, Beirut: Muassasah alRisalah, cet.1, 2004.

Abu Bakr Ahmad ibn al-Hussain al-Bayhaqi, al-Madkhal ila as-Sunani al-Kubra, Kuwait: Dar al-Khulafa lil Kutub al-Islami, t.c, 1404H.

At-Tirmidzi, Sunan at-Tirmidzi, Beirut: Dar al-Gharib al-Islamiy, cet.1, 1996.

Abu Ishaq al-Shatibi, Al-Muwafaqat fi Ushul al-Shariah, Kaherah: Dar Ibn Affan, cet1, $1417 \mathrm{H} / 1997$.

Adil al-Shuwaikh, Ta'lil Al-Ahkam Fi Al-Shariah Al-Islamiyyah, Tanta: Dar al-Bashariyah Lil Saqafah Wa al-Ulum, cet.1, $1420 \mathrm{H} / 2000$.

Creswell John W., 2010, Research Design: Qualitative, Quantitative, and Mixed Methods Approaches, 3th, terjemahan Achmad Fawaid, Yogyakarta.

Gary Anderson, Nancy Arsenault, 1998, Fundamentals of Educational Research, 2nd Edition, The Falmer Press, Philadelphia.

Ibn Hazm, al-Ihkam Fi Usul al-Ahkam, Beirut: Dar al-Afaq al-Jadidah, t.t.

Ibn Hazm, al-Muhalla Bial-Atsar, Beirut: Dar al-Kutub al-Ilmiyyah, cet.3, 2003.

Iskandar, Metodologi Penelitian Kualitatif, Jakarta: Gaung Persada, 2009.

Jamal al-Din Abi Amr Uthman bin 'Amr ibn al-Hajib, Muntaha al-Wusul wa al-Amal fi 'Ilmay al-Usul wa al-Jadal, Beirut: Dar al-Kutub al-Ilmiyyah, cet.1, 1985.

Maad Ahmad, Muhammad Yosef Niteh, Mohd Rofaizal Ibrahim, Antara Akal dan Wahyu Dari Perspektif Islam, E-Prosiding Persidangan Antarabangsa Sains Sosial dan Kemanusiaan, Jilid 2, Kolej Universiti Islam Antarabangsa Selangor, KUIS, Malaysia, 2017.

Mahmood Zuhdi Ab Majid (2000), "Fiqh Malaysia: Konsep dan Cabaran", dalam Paizah Ismail dan Ridzwan Ahmad, Fiqh Malaysia, Kuala Lumpur: Akademi Pengajian Islam, Universiti Malaya.

Mahmood Zuhdi Haji Abd Majid, Maqasid Syariah Sebagai Pendekatan Bagi Realisasi Ajaran Islam di Malaysia: Satu Prospek. https://www.academia.edu/30256412/ maqasid_syariah_sebagai_pendekatan_bagi_realisasi_ajaran_islam_di_malaysia_ satu_prospek.

Mohd Ramli, Muhammad Sayuti Mansor, Lufti Juwaini, Pendekatan Wasatiyyah Bagi Menangani Ikhtilaf Fiqh Dalam Kalangan Masyarakat Islam Nusantara, Seminar 
Internasiolan "Islam di Alam Melayu kali ke-V ", 12-14 September 2015 di College of Islamic Studies Prince of Songkla University, Pattani, Thailand.

Muhamamad Rashidi Wahab, Mohd Faizul Azmi, Kedudukan Akal dalam Pendalilan Akidah, Jurnal: Teknologi, Vol.63, No.1 Juli 2013.

Muhammad al-Bahi, al Fikr al Islami fi Tatawwurih, Kaherah: Dar al Fikr, 1971, hal 7.

Muhammad Ben Umar, Ibn Hazm Wa Arauhu al-Ushuliyyah, Beirut: Dar al-Kutub alIlmiyah, cet.1, 2007.

Muhammad Mansif al-Asri, Al-Fikr al-Maqasidi Inda al-Imam Malik, Kaherah: Dar alHadith, 2008.

Muhammad Ropingi, Posisi Akal dalam Perspektif Dalil Akidah, Jurnal: Risalah, Vol. 4, No.2 Januari 2018.

Muhamamad Rashidi Wahab, Mohd Faizul Azmi, Kedudukan Akal dalam Pendalilan Akidah, Jurnal: Teknologi, Vol.63, No.1 Juli 2013.

Muhammad Said al-Yubi, Maqasid al-Shariah al-islamiyyah Wa 'Alaqatuha Bi al-Adillah al-Shar'iyyah, Riyadh: Dar al-Hijrah, cet.1, 1418H/1998.

Muhammad al-Amidi, Ghayat al-Maram fi 'Ilm al-Kalam, Tahqiq: Hasan Mahmud 'Abd al-Latif, Kaherah: al-Majelis al-'Ala lil Suun al-Islamiyah, t.t.

Muslim, Shahih Muslim, Beirut: Dar al Fikr, cet.1, 1424H/2003.

Ridzwan Ahmad, Permasalahan Ta'lil Al-Ahkam Sebagai Asas Penerimaan Maqasid AlShariah Menurut Ulama Usul, Jurnal fiqh, vol 5, Kuala Lumpur: Akademi Pengajian Islam Universiti Malaya, 2008.

Syuhada, Bagaian Waris Ibu Dalam Gharrawayn: Analisis ljtihad Umar Dan Ibn Abbas Dalam Bagian Waris Ibu, Jurnal Tafaqquh, Vol.2, No.1, Juni 2014.

Umar Shalih Umar, Maqasid al-Shariah inda al-Imam al-izz Ibn Abd al-Salam, Urdun: Dar al- Nafais, cet.1, 1423H/2003.

Wahbah al-Zuhayli, Usul al-Figh al-Islami, (Damshiq: Dar al-Fikr, cet.1, 1406H/1986).

Ziyad Muhammad Ahmidan, Maqasid al-Shariah al-Islamiyyah, Beirut: Muassasah alRisalah Nashirun, cet.1, 1429H/2008. 
Asy-Syari'ah (P-ISSN: 2086-9029 E-ISSN: 2654-5675) is a periodical scientific journal that publishes various results of studies and research, literature review, and other scientific works whose scope covers the field of Islamic law/sharia, law and society in monodisciplinary, interdisciplinary, and multidisciplinary manners. The journal aims to expand and create innovative concepts, theories, paradigms, perspectives and methodologies in the above said scope. The Journal is published twice a year (june and december) by Faculty of Shariah and Law, Sunan Gunung Djati State Islamic University Bandung in collaboration with Asosiasi Sarjana Syariah Indonesia (ASSYI).

\section{EDITORIAL OFFICE:}

Fakultas Syariah dan Hukum UIN Sunan Gunung Djati Bandung J1. Raya A.H. Nasution No. 105 Cibiru Kota Bandung, 40614

Tlp/Fax: +022-7802278 Faks. 022-7802278

Website http://journal.uinsgd.ac.id/index.php/asy-syariah/index

E-mail: Jurnalasy-syariah@uinsgd.ac.id 